\title{
Palynological evidence of vegetation change during the last 10,000 years in the mid-valley of the Rio Doce, Brazil
}

\section{Fernanda Mara Fonseca-Silva ${ }^{1 *}$ (1), Marcelo de Araujo Carvalho ${ }^{2}$ (1) and Sérvio Pontes Ribeiro ${ }^{3}$ (1)}

Received: April 4, 2018

Accepted: August 16, 2018

\begin{abstract}
In order to reconstruct the vegetation history of the last 10.000 years, palynological analyses were carried out using 17 sedimentary samples of a core drilled in Parque Estadual do Rio Doce (PERD-MG). Twenty-one species of fern spores, 52 species of pollen grains and six species of fungi were identified. Phase 1 (10.375 - 9.350 cal. years BP) is characterized by a low concentration and diversity of pollen grains and is thus interpreted as a fluvial system with the presence of coarse-grained sediments. Phase 2 (9.062 - $8.195 \mathrm{cal}$. Years BP) is interpreted as a transition from a fluvial to lacustrine environment. Phase 3 (7.905 - 4.785 cal years BP) is characterized by increased trend of palynomorph concentration, highlighted by a high abundance and diversity of fern spores, which are indicative of a more a humid condition. The uppermost phase, Phase 4 (4.785 - $50 \mathrm{cal}$. Years AP), possessed a lower abundance of herbaceous flora, which is replaced by other vegetation groups (e.g. marsh, cerrado, Atlantic Forest). The uppermost sample represents the contemporary environment ( 50 years), which is characterized as seasonally-flooded.
\end{abstract}

Keywords: Holocene, paleovegetation, Parque Estadual do Rio Doce (PERD), pollen analysis, South America

\section{Introduction}

The hydrographic basin of the Rio Doce (Doce River) is located in the Southeast Region of Brazil, between $18^{\circ} 45^{\prime}-21^{\circ} 15^{\prime} \mathrm{S} 39^{\circ} 55^{\prime}-43^{\circ} 45^{\prime} \mathrm{W}$. The basin covers a drainage area of $83,400 \mathrm{~km}^{2}$ including the ca. 37.000 ha Parque Estadual do Rio Doce (PERD) in the Vale do Aço region of the southwestern portion of the state of Minas Gerais. The PERD is bordered to the north and east by the Rio Piracicaba and the Rio Doce, respectively; to the west by the municipalities of Marliéria and Timóteo; and to the south by the municipality of Dionísio.

The PERD is a system composed of approximately 160 lakes (ca. $10 \%$ of its area) and around 40 lakes and ponds in advanced stages of sedimentation. The origin of this system remains controversial. According to Pflug (1969), the system originated as the result of the closing of secondary valleys of the Rio Doce since the end of Pleistocene. Meis (1978) concluded that the sediment types present indicate changes in paleoenvironmental and paleohydrological conditions during the Holocene. Mello (1997) concluded that the origin of the lake complex is mainly related to local neotectonic activity, with the first phase being East-West (EW) dextral transcurrent action beginning in the Late Pleistocene. The second phase of tectonic movements occurred during the Middle Holocene and was characterized as a Northwest-Southeast (NW-SE) extensional regime. These actions produced faults and consequent unevenness and tilting of watercourses of the tributary channels of the Rio Doce, thus acting as dams and giving rise to lake systems.

1 Programa de Pós-Graduação em Evolução Crustal \& Recursos Naturais, Departamento de Engenharia Geológica, Universidade Federal de Ouro Preto, 35400-000, Ouro Preto, MG, Brazil

2 Laboratório de Paleoecologia Vegetal, Departamento de Geologia \& Paleontologia, Museu Nacional, Universidade Federal do Rio de Janeiro, 22040-040, Rio de Janeiro, RJ, Brazil

3 Departamento de Biodiversidade, Evolução \& Meio Ambiente, Universidade Federal de Ouro Preto, 35400-000, Ouro Preto, MG, Brazil

* Corresponding author: fernandamarafonseca@gmail.com 
Considerable work has attempted to assess the paleoenvironmental changes that occurred during the Quaternary of the Rio Doce area (Overloop 1981; Ybert et al. 1997; Mello et al. 1999; Rodrigues Filho et al. 2002; Justo 2003; Perônico 2008). The area comprises the largest natural lacustrine system in South America: the mid-valley of the Rio Doce (Gilhuis 1986; Veloso et al. 1991), specifically within the Parque Estadual do Rio Doce (PERD), which is presently in the Atlantic Forest domain.

Documentation of floral changes is one of the best tools for discovering the evolution of this paleoenvironment. Palynological studies dealing with Holocene sediments in the lacustrine system of PERD have been carried out since Overloop (1981) to the present and have contributed greatly to understanding changes in vegetation and climate.

The aim of the present study was to reconstruct the historical vegetation of the mid-valley of the Rio Doce from one core of $90 \mathrm{~cm}$ (LC-02) collected in PERD, using botanical taxonomy and quantitative analysis of pollen data. The palynological data are expected to facilitate reconstructions of the paleoenvironment and to document changes in vegetation.

\section{Materials and methods}

Study area

The PERD covers ca. 37,000 ha and is located in the Vale do Aço region in the southwestern portion of the state of
Minas Gerais. The park is bordered to the north and east by Rio Piracicaba and Rio Doce respectively; to the west by the municipalities of Marliéria and Timóteo; and to the south by the municipality of Dionísio (Fig. 1).

The hydrographic basin of the Rio Doce covers a drainage area of $83,400 \mathrm{~km}^{2}$, with $86 \%$ within the state of Minas Gerais and $14 \%$ within the state of Espírito Santo. The PERD is a system composed of approximately 160 lakes (ca. 10\% of its area) and around 40 lakes and ponds in advanced stages of sedimentation. The origin of this system is remains controversial, although there are two main hypotheses: 1) climatic change with the contribution of periods of glaciation; and 2) tectonic activity.

According to Pflug (1969), the system originated as the result of the closing of secondary valleys of the Rio Doce since the end of Pleistocene. Meis (1977) and Meis \& Monteiro (1979) suggested that the sediment types present indicate changes in environmental and hydrological conditions during the Holocene.

Mello (1997) suggested that the origin of the lake complex is mainly related to local neotectonic activity, with the first phase being East-West (EW) dextral transcurrent action beginning in the Late Pleistocene. The second phase of tectonic movements occurred during the Middle Holocene and is characterized as a Northwest-Southeast (NW-SE) extensional regime. These actions produced faults and unevenness and tilting of watercourses of the tributary channels of the Rio Doce. The morphological and sedimentological features of the middle Rio Doce reflect
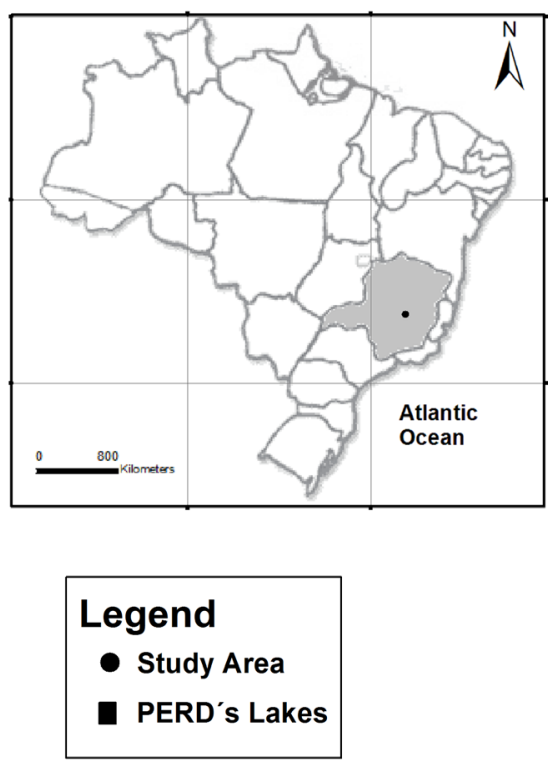

Drawing: Fonseca-Silva, 2015 DATUM Sirgas 2000 / Coord: UTM Source: Modify Barbosa \& Kohler, 1981.

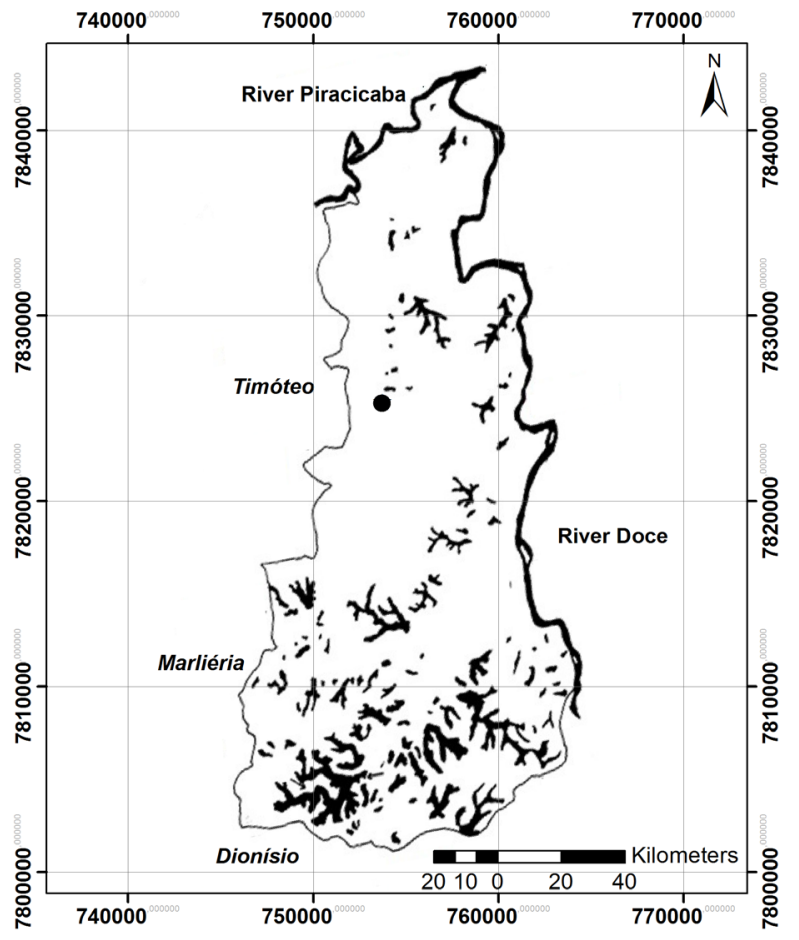

Figure 1. Location of the study area, Parque Estadual do Rio Doce (PERD), state of Minas Gerais, Brazil (modified from Barbosa \& Kohler 1981). 
interactions between climatic conditions and tectonic activity (Overloop 1981; Mello 1997; Ybert et al. 1997; Mello et al. 1999; Vasconcelos \& Saadi 2003; Lorente 2007; Perônico 2008).

Recent studies have shown that a change from a fluvial system to a lake system occurred ca. 8,500 years B.P. (Fonseca-Silva et al. 2015). The first lake submersion was dated by Mello (1997), and corroborate by Fonseca-Silva et al. (2015), at around 9,000 years BP.

\section{Climate and vegetation framework}

The climate in the state of Minas Gerais is defined as tropical semi-humid, with humid summers, dry winters, and mesothermal features (Nimer 1989). Average temperatures range from 20 to $22^{\circ} \mathrm{C}$, with a typical tropical rainfall system with an average annual rainfall of $1,500 \mathrm{~mm}$ for the lowland region of Rio Doce and less than 1,000 $\mathrm{mm}$ in other areas.

The contemporary vegetation of the state of Minas Gerais is composed of basically two main biomes: Atlantic Forest and Cerrado (savanna woodlands). The former occupies less area of the state than the latter (Fig. 2), comprises dense and permanently green vegetation, and has a high pluviometric index. Families such as Bromeliaceae, Bignoniaceae, Lauraceae and Orquidaceae, as well as ferns (e.g., Polypodiaceae), and several species of lichens have been recorded in this biome (IEF 2010). The Cerrado, on the other hand, is a vegetation mosaic, with continuous grasslands containing scattered trees and/or bushes. The Cerrado thus possesses a structurally intermediate landscape between forest and grasslands, and thus represents a typical savanna (Ratter et al. 2003). Common taxa of the Cerrado include Urticaceae (Cecropia sp. - embaúba), Euphorbiaceae (Croton sp. - sangue-de-dragão), Fabaceae (Anadenanthera colubrina - angico), Asteraceae (Eremanthus sp. - candeia), and Melastomataceae (Tibouchina sp. and Miconia sp. quaresmeiras) (Walter, 2006). The Cerrado is biodiverse and has a great extension, coming into contact and establishing transitional areas with almost all other biomes of Brazil (Ribeiro 2002; Sano et al. 2008).

The area of PERD (Fig. 1) is one of the largest continuous areas of tropical forest in the state of Minas Gerais, and possesses high diversity and abundance of flora and fauna. According to Gilhuis (1986), the area is considered a remnant of Atlantic Forest, although there is also semi-deciduous sub-montane and deciduous forest present (Veloso et al. 1991). The vegetation of PERD currently comprises a mosaic of primary and secondary forest, the latter being the result of large fires that occurred mainly in the 1960's (SOCT 1981), leading Lopes et al. (2002) to suggest the occurrence of secondary succession in some parts of the forest.

Phytosociological analysis performed by Lopes et al. (2002) demonstrated the predominance of Bixa arborea (Bixaceae), Guatteria schomburgkiana (Annonaceae), Joannesia princeps (Euphorbiaceae), Aparisthmium cordatum (Euphorbiaceae), Pseudopiptadenia contorta (Fabaceae) and Carpotroche brasiliensis (Achariaceae).

\section{Collected core}

The single core was collected from a sedimentary profile of a lake the in north-central region of PERD near the Salão

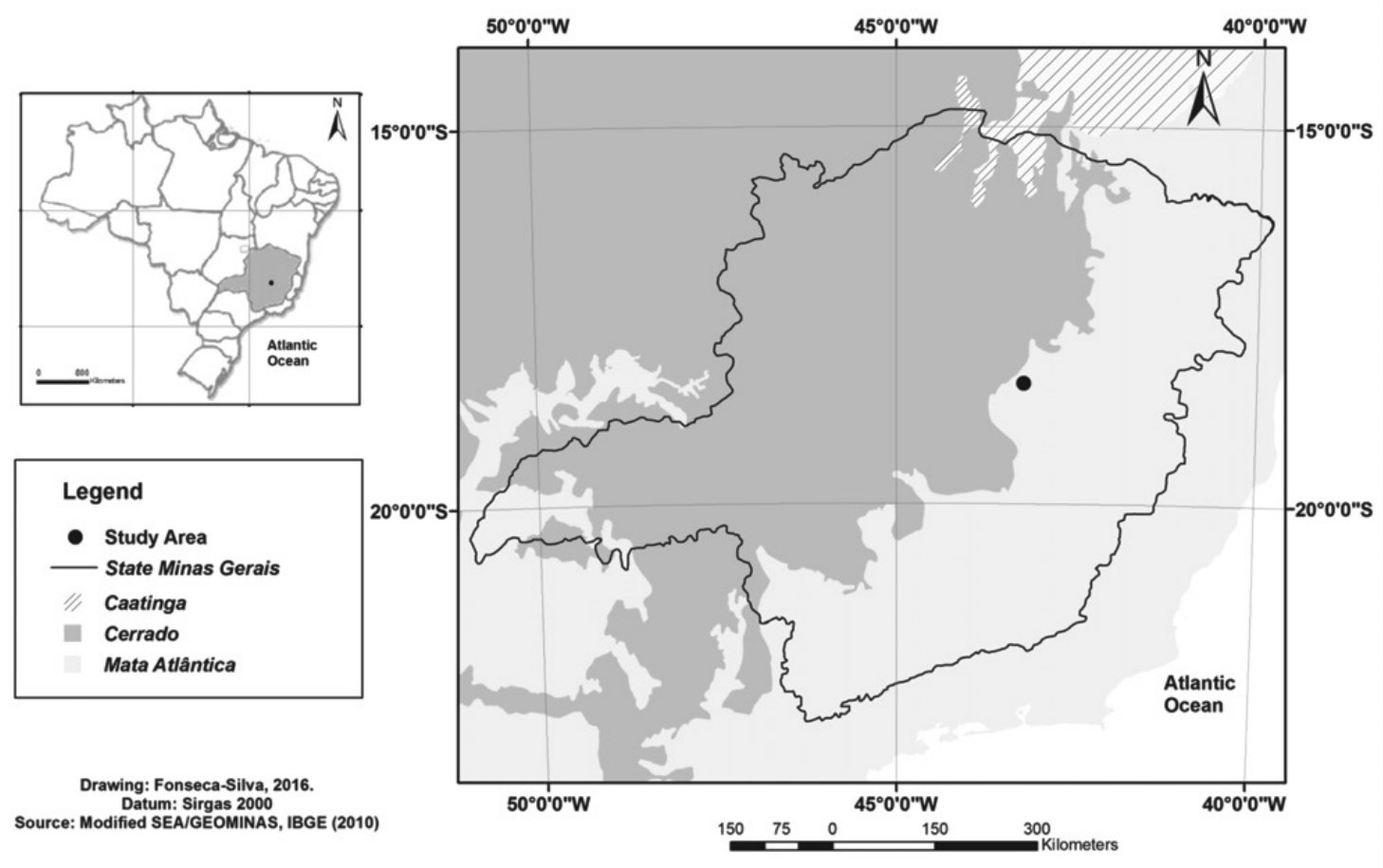

Figure 2. Vegetation of the state of Minas Gerais, Brazil (modified from Geominas 2010). 
Dourado guardhouse. The lake (LC2) is bordered by native vegetation but part of its western margin lies outside of the boundaries of PERD. A body of water still remains at its center, but the two main "arms" are silted. The sediment core (Lc2-01) was collected from the central part of the lake at $19^{\circ} 39^{\prime} 01^{\prime \prime} \mathrm{W} 42^{\circ} 34^{\prime} 47^{\prime \prime} \mathrm{S}(753743.00 \mathrm{~W} / 7825362.00 \mathrm{~S}$ UTM/SIRGAS 2000). It is $90 \mathrm{~cm}$ (Fig.2) long (deep) and was sampled every $5 \mathrm{~cm}$ for a total of 17 samples.

The 17 samples (10-20 g of sediment) were prepared at the Laboratório de Geoquímica (DEGEO) of Universidade Federal de Ouro Preto (UFOP) and in the Laboratório de Paleoecologia Vegetal, Departamento de Geologia e Paleontologia, Museu Nacional, Universidade Federal do Rio de Janeiro (UFRJ). Five-gram samples of dry sediment were processed for palynomorph extraction with hydrochloric $(\mathrm{HCl})$ and hydrofluoric $(\mathrm{HF})$ acid, following an adaptation of the methodology proposed by Ybert et al. (1992). According to this method, all mineral constituents are destroyed by the acids before heavy-liquid separation, with the remaining organic matter being sieved through a $50 \mu \mathrm{m}$ mesh and mounted on slides. The slides were analyzed under a transmitted light microscope and at least 300 palynomorphs were counted on each slide.

To determine total organic carbon (TOC) was used the induction furnace of the WR-12 LECO carbon determiner, from an infrared detector and analyzer SC-144DR LECO. The procedure was performed at the X-Ray Diffraction Laboratory / DEGEO / UFOP.

Pollen was identified using mainly morphological features, such as polarity, size, amb (shape and symmetry), and exospore ornamentation. Regarding scars or laesurae, spores can be alete (no laesura), monolete (single laesura), or trilete (three laesurae). Descriptive terminology follows the International Code of Botanical Nomenclature (ICBN), glossaries of pollen grains and spore terminology Punt et al. (2007), Ybert et al. (2012), Justo (2003), Leal \& Lorscheitter (2006), Leonhardt \& Lorscheitter (2007), Freitas et al. (2007), Gomes (2008), Perônico (2008), Lorente (2010), Cassino (2010), and Cassino \& Meyer (2011; 2013).

Palynomorphs were grouped into five main vegetation groups and algae according to Cassino \& Meyer (2013) (Tab. 1): swamp, cerrado, Atlantic forest, gallery forest and altitudinal forest.

Quantitative analysis of palynomorphs consisted of counting only the pollen grains (excluding spores, algae and fungi) found on the palynological slides. A sum of 300 pollen grains was counted per sample. Spores and nonpollen material were identified and counted separately. Pollen diagrams were constructed using the software $C 2$. To reconstruct paleovegetation trends, the ShannonWeaver diversity index $(\mathrm{H}(\mathrm{S})$ ) was calculated for all samples using PAST software. This index takes into account the abundance of each species and is used to characterize the diversity of assemblages. To estimate the degree of species turnover, Detrended Correspondence Analysis (DCA) (Hill 1975) was performed using PAST (Hammer et al. 2008), based on the explanation of Toledo \& Bush (2008). The matrix used included taxa with percentage values, and sample scores from axis 1 were plotted against sample depths $(\mathrm{cm})$.

Table 1. Vegetational groups of the study area, Parque Estadual do Rio Doce (PERD), state of Minas Gerais, Brazil.

\begin{tabular}{|c|c|c|c|c|c|}
\hline Algae & Altitudinal forest & Cerrado & Forest & Gallery forest & Swampy \\
\hline Pseudoschizaea rubina & Dicksonia sp. & Acalypha schiedeana & Alchornea sp. & Blechnum sp. & Anemia sp. \\
\hline \multirow[t]{22}{*}{ Spirogyra cf. scrobiculata } & Hedyosmum brasilienese & Annona sp. & Alsophila sp. & Cheilanthes sp. & Anogramma sp. \\
\hline & Ilex sp. & Arrabiadaea sp. & Anacardiun sp. & Cyathaceae Type 1 & Aspilia sp. \\
\hline & & Bowdichia sp. & Baccharis sp. & Cyathaceae Type 2 & Cyperaceae \\
\hline & & Butia & Cabralea canjerama & Cyathea sp. & Lycopodiella lopecuroides \\
\hline & & Caesalpinioideae & Emmeorhiza sp. & Gleichenia sp. & Lycopodiella caroliniana \\
\hline & & Camarea sp. & Eupatorium sp. & Pityrogramma sp. & Lycopodiella cernua \\
\hline & & Cassia sp. & Heteropterys sp. & Polypodium sp. & Mauritia flexuosa \\
\hline & & Chamaesyce sp. & Leandra sp. & Sapindus sp. & Pistia sp. \\
\hline & & Commiphora leptophloeos & Lophosoria sp. & Thelypteris sp. & Senecio sp. \\
\hline & & Ericaceae & Ludwigia sp. & & Tragia lagoensis \\
\hline & & Eriotheca sp. & Malvaceae Type 1 & & Typha sp \\
\hline & & Eugenia sp. & Microlicia sp. & & Vernonia sp. \\
\hline & & Fabaceae Type 1 & Mikania sp. & & \\
\hline & & Maprounea brasiliensis & Mimosa sp. & & \\
\hline & & Peixotoa sp. & Protium sp. & & \\
\hline & & Poaceae * Polygonum sp. & Psychotria sp. & & \\
\hline & & Pseudobombax sp. & Pteris sp. & & \\
\hline & & Sena sp. & Sebastiania sp. & & \\
\hline & & & Stryphnodendron sp. & & \\
\hline & & & Tabebuia sp. & & \\
\hline & & & Tetrapterys sp. & & \\
\hline & & & Urvillea sp. & & \\
\hline
\end{tabular}


To establish the chronology of the studied core, 04 levels of carbonaceous material were radiocarbon $\left({ }^{14} \mathrm{C}\right)$ dated. Dating was not possible at the level of $90-\mathrm{cm}$ deep. The dated ranges were $80 \mathrm{~cm}, 65 \mathrm{~cm}, 35 \mathrm{~cm}$ and $07 \mathrm{~cm}$ deep, as defined by changes observed in the polynic analysis (Tab. 2). The samples were analyzed by Beta Analytic Inc (C) Laboratory (Florida, USA), which provided the calibrated ages. The specific age of each sample was obtained by linear interpolation, while the samples out of dated range were obtained by extrapolation.

Table 2. Calibration intervals for the $\mathrm{C} 14$ ages of the Lc2-01 core.

\begin{tabular}{|c|c|c|c|c|}
\hline $\begin{array}{c}\text { Depth } \\
\text { (cm) }\end{array}$ & $\begin{array}{c}\text { Laboratory } \\
\text { number }\end{array}$ & $\begin{array}{c}\text { Measured age } \\
\left({ }^{1} \mathbf{C} \text { yr B.P.) }\right.\end{array}$ & $\begin{array}{c}\text { Calibrated age (cal } \\
\text { yr B.P., 2 o) }\end{array}$ & $\begin{array}{c}\text { Interpolated age } \\
\text { (cal yr B.P.) }\end{array}$ \\
\hline 0 & Beta 328004 & $101.3+/-0.4$ & 102.3 & $51^{*}$ \\
\hline 5 & & & & 102 \\
\hline 10 & & & & 1403 \\
\hline 15 & & & & 2703 \\
\hline 20 & & & & 4004 \\
\hline 25 & & & & 5304 \\
\hline 30 & & & & 6605 \\
\hline 35 & Beta 366683 & $7100+/-40$ & $7970-7840$ & $7905 \#$ \\
\hline 40 & & & & 8194 \\
\hline 45 & & & & 8483 \\
\hline 50 & & & & 9772 \\
\hline 55 & & & & 9062 \\
\hline 60 & & & & $9640 \#$ \\
\hline 65 & Beta 365497 & $8790+/-40$ & $9650-9630$ & 9824 \\
\hline 70 & & & & 10,010 \\
\hline 75 & & & & $10,375 \#$ \\
\hline 80 & Beta 328008 & $9210+/-50$ & $10,510-10,240$ & $11,023^{*}$ \\
\hline 85 & & & & \\
\hline
\end{tabular}

* Extrapolated age. \# Mean calibrated age.

Changes in paleovegetation were evidenced from agglomerative, hierarchical clustering and stratigraphically constrained analyses (Tilia) (Grimm 1987) for all palynomorphs (Fig. 3) and the five main vegetation groups (swamp, cerrado, Atlantic forest, gallery forest and altitudinal forest) and algae (Fig. 4). The distribution of taxa revealed four zones (ZA-ZD): Zone A (from 10,375 cal. yr BP until 9,350 cal. yr BP); Zone B (from 9,062 cal. yr BP until 8,195 cal. yr BP); Zone C (from 7,905 cal. yr BP until 4,785 cal. yr BP) and Zone D (from 4,785 cal. yr BP 50 yr BP).

\section{Results and discussion}

\section{Chronology}

All ages used henceforth are interpolated calibrated years (cal. yr) before present (BP). The basal age of 10,375 cal. yr BP for Lc2 core indicate a Holocene history. Fonseca-Silva et al. (2015) showed that sedimentary rates were not constant overtime, being faster between 10,375 and 7,905 cal. yr B.P., and were related to the fluvial environment, and slowing up core (from 7,905 cal. yr B.P.), reflecting the lake phase.

\section{Changes in paleovegetation}

Although a great number of pollen types were identified, the majority was rare. Preservation was moderate to excellent. A total of 70 palynomorph types were identified in the studied samples (Fig. 4), of which 51 were pollen grains, 17 were fern spores (with one lycophyte - bryophyte), and two were freshwater algae (Pseudoschizaea sp. and Spirogyra sp.), along with fungal spores.

Overall, the non-arboreal taxa Cyperaceae (21\%), Poaceae $(19 \%)$ and the fern Blechnum sp. $(14 \%)$ were the most abundant taxa in the fossil pollen spectra, totalling $>46 \%$ in most samples. Pollen concentration ranged from ca. $27 \times 103$ to $200 \times 103$ grains $\mathrm{cm}^{-3}$.

The Shannon-Weaver diversity index ranged from 1.22 to 3.38 (average $=2.25$ ). The diversity values varied throughout the record with the lowest values being recorded at the basal part of the Lc02-1 core and an increasing trend upwards. In general, periods of higher palynological diversity corresponded to periods of high abundance of gallery forest and cerrado.

The first axis of the DCA explained $78 \%$ of the variance in the data, which represents an estimate of the amount of palynological compositional change or compositional turnover within the considered time period. The DCA-score curve is very similar to the Shannon-Weaver diversity index suggesting that this was responsible for the changes in vegetation (increasing of diversity).

Among zones, the most obvious distinction was between zones $B$ and $C$, which showed an increase in pollen concentration and TOC. Moreover, there was a decreasing trend in sediment granulometry (sand to mud), indicating the change from the fluvial to the lake environment.

\section{Zone A $(10,375$ - 9,350 cal. yr BP)}

The lowermost zone, Zone A, corresponded to the interval between 85.0 and $73.0 \mathrm{~cm}$ with an estimated duration of 1.025 years. The zone is in coarse-grained sediments (> 50\%) with low TOC values (Fig. 5), indicating quick sedimentation. The X-ray analysis indicated high content of muscovite, which is provenient to the basement rocks and resistant to weathering. When combined with quartz, muscovite can indicate fluvial transport (Oliveira et al. 2002). Zone A is coincident with Phase 1 of Fonseca-Silva et al. (2015), which was interpreted as a fluvial environment. The low values for pollen concentration, TOC and diversity (Fig. 5) are related to the coarse-grain of the fluvial system.

Few palynomorphs were found in the Zone A, and are represented by herbaceous taxa (Poaceae and Cyperaceae), which probably indicates open habitats. Taxa of Poaceae decrease throughout the zone, while taxa of Cyperaceae increase slightly. The taxa of shrubs and herbs present (22.7\%) are represented by Ilex sp. (6.1\%) Aspilia sp. (1.9\%), Baccharis sp. (1.5\%), Senecio sp. (1.9\%) and Vernonia sp. 


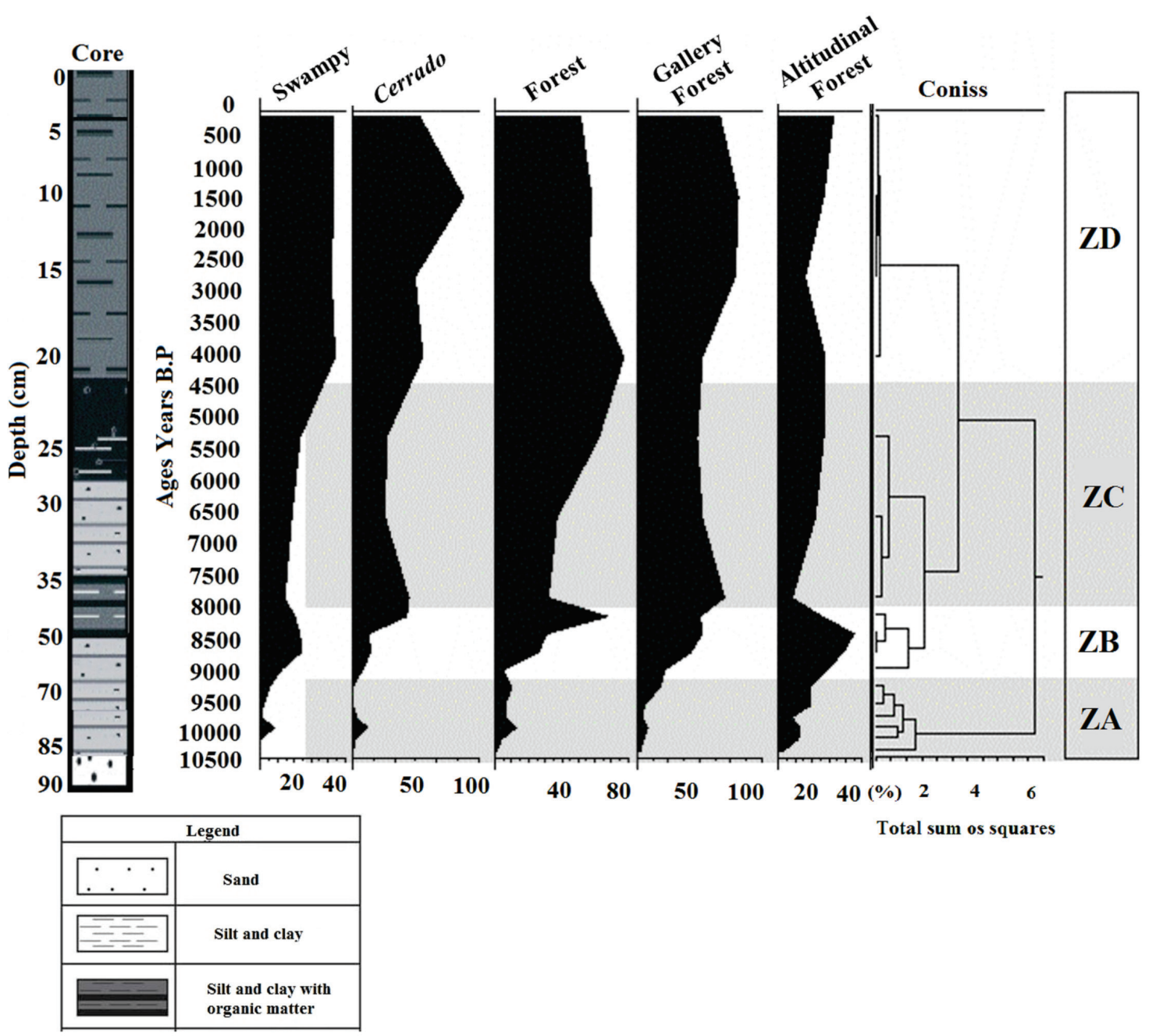

Figure 3. R-mode dendrogram of Lc2-01 core showing palynology assemblages.

(2.5\%) (Fig. 3). The most common shrubs are of the genus Ilex, which have been found in altitudinal areas in South and Southeast Brazil (Mendonça et al. 2008) (Fig. 5). Other taxa are present in small (>1\%) quantities (e.g., Camarea sp., Peixota sp., Mimosa sp., Borreria sp., Similax sp.). The small quantities of pollen, low TOC values and high particle size may reflect a fluvial environment. This interpretation corroborates the study of Mello (1997) that suggested a fluvial environment up to 9,000 cal. yr BP.

\section{Zone B $(9,062-8,195$ cal. yr BP)}

The sediments of Zone B consist of an intercalation of sand and organic matter, indicating a transition from a fluvial to a lacustrine environment. The lowest concentrations of pollen occur in this zone, as also indicated by low TOC values (Fig. 5). However, the granulometry decreases upwards throughout the zone suggesting the initiation of a lacustrine system.

The DCA shows a change in flora within Zone B, indicating that there was a significant change in the overall plant assemblage, especially regarding Cyperaceae. Although, herbaceous vegetation dominates, all vegetation groups increase in this zone (Fig. 4), reflecting an increase in diversity. The significant presence of altitudinal flora, especially the shrub species Hedyosmum brasiliense (peak at 8,485 yr BP) (Marchant et al. 2002), indicates vegetation typical of a humid and altitudinal environment.

Mauritia flexuosa is first recorded in this zone (at $9.350 \mathrm{yr} \mathrm{BP}$ ), which is an indicator of contemporary palm swamps today, accompanied by low values for Ludwigia sp. (0.7\%) (Onagraceae), Heteropterys sp. (0.3\%) and Tetrapterys sp. (0.5\%) (Malpigiaceae), Microlicia sp. (0.1\%) (Melastomataceae), Psychotria sp. (1.1\%) (Rubiaceae), Polygonum sp. (1.9\%) (Polygonaceae), Sapindus sp. (0.3\%) (Sapindaceae), Gleichenia sp. (3.8\%) (Gleicheniaceae), and Lycopodiella alopecuroides (1.3\%) (Fig. 3). These vegetation communities support the hypothesis that there was a swampy or water-logged forest (Medeiros 2011), which is corroborated by the first certain recorded of the presence of algae, particularly Spirogyra (5.1\%). This genus is usually recorded in abundance in shallow and clean bodies of 

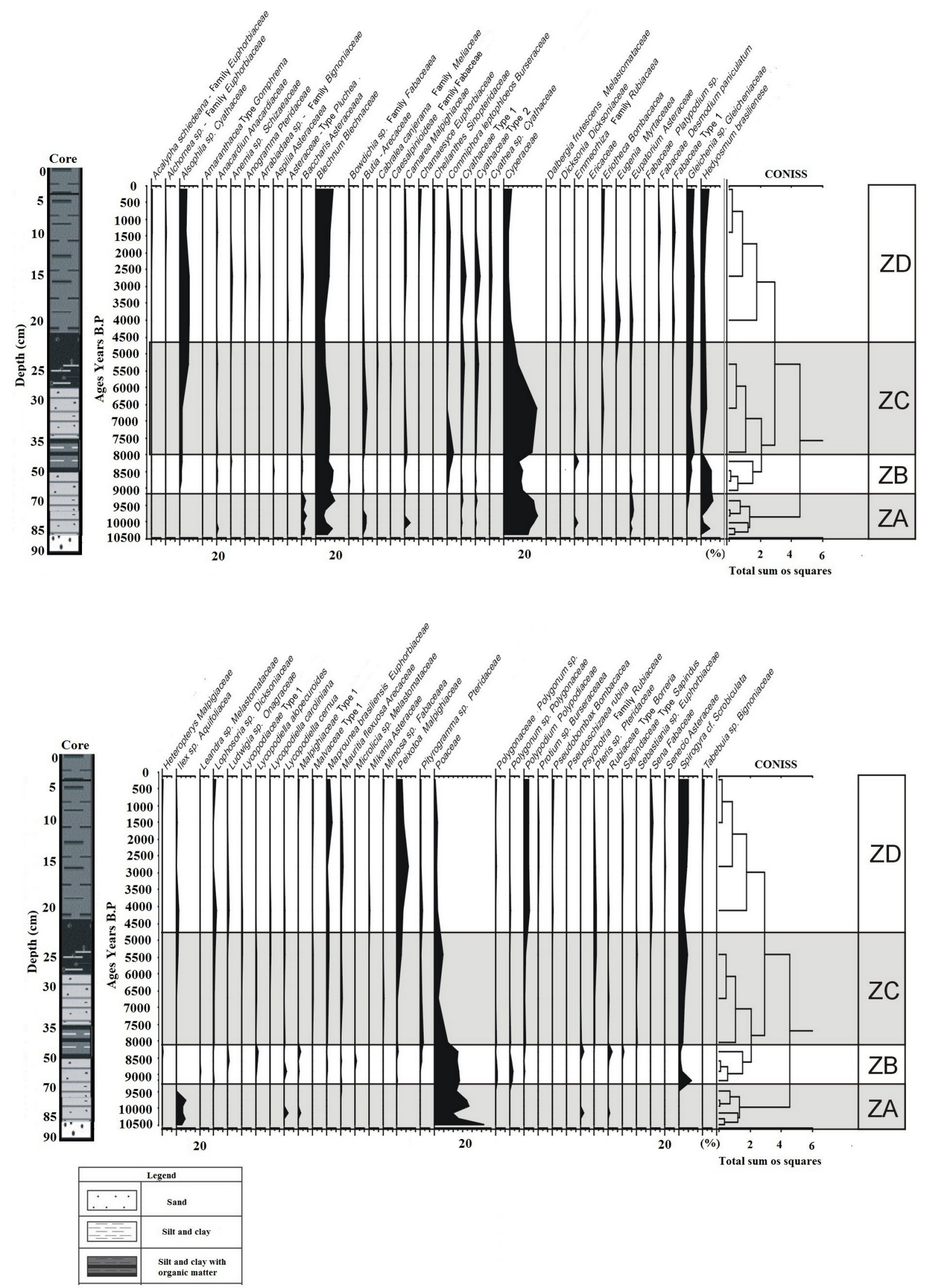

Figure 4. Q-mode dendrogram of Lc2-01 core showing the depositional phase; age showing depositional phases obtained from the Q-mode dendrogram. 


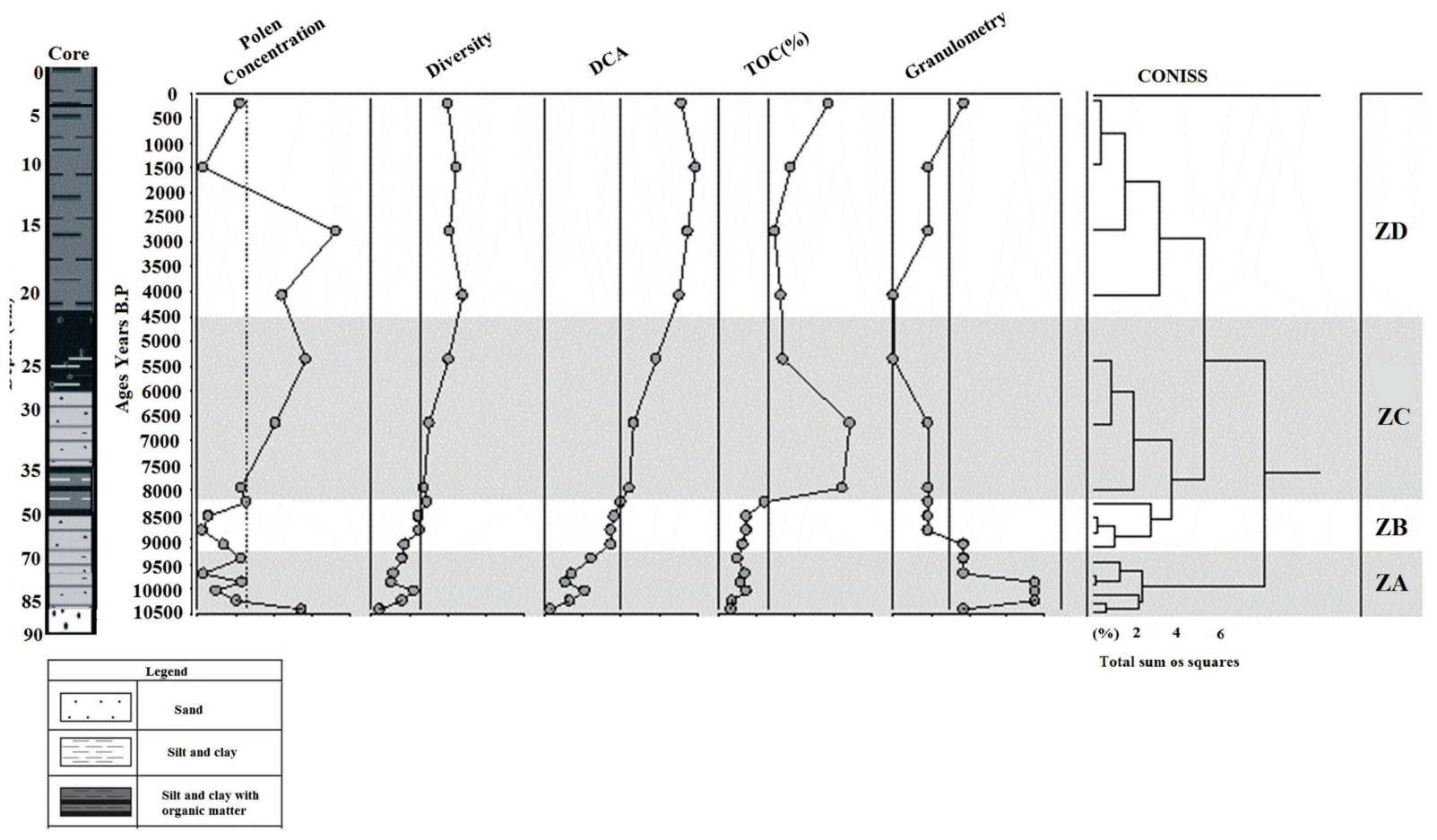

Figure 5. Q-mode dendrogram of Lc2-01 core showing pollen concentration, diversity, DCA scores, TOC (\%) and granulometry.

freshwater with low flow but seasonal heating (Grenfell 1995; Algaebase 2012). Pseudoschizaea sp. (0.1\%) was also recorded, though without botanical affinity, and is usually assigned to the algae. The genus is common in marsh sediments.

According Fonseca-Silva et al. (2015), the same interval can be interpreted as a transition from a fluvial to a lacustrine environment, which corresponds to the first lacustrine incursion in PERD at $~ 9,000$ years B.P, as recorded by other studies as well (Meis 1977; 1978; Overloop 1981; Barbosa \& Kohler 1981; Mello 1997; Ybert et al. 1997; Mello et al. 1999; Justo 2003; Perônico 2008; Fonseca-Silva et al. 2015).

\section{Zone C (7,905-4,785 cal. yr BP)}

Zone $C$ with the lacustrine system installed, and represents the initiation of the accumulation of finegrained sediments (muds and clays), and thus increased organic matter as indicated by higher values of TOC. Furthermore, such fine-grained sedimentation, which is usually characteristic of lacustrine environments, favors increased recovery palynomorphs. The presence of algae also indicates the presence of a waterbody (lake). The abrupt decrease of pollen of Poaceae and increase of that of Cyperaceae is evidenced by the DCA curve that illustrates the transition from Zone $B$ to Zone $C$. Other pollen taxa present in small quantities include Ilex sp. (1.3\%), Camarea sp. (0.7\%), Peixota sp. (2.9\%), Butia sp. (2.3\%), Baccharis sp. (0.5\%), Sena sp. (0.3\%), Senecio sp. (0.1\%) and Vernonia sp. (1.9\%) (Fig. 5).

High abundance and diversity of pteridophytes is also recorded in Zone $C$, being represented by Anemia sp. (Schizaeaceae), Cheilanthes sp., (Sinopteridaceae), Dicksoniaceae (Lophosoria sp., Dicksonia sp., Lycopodiella alopecuroides, Lycopodiella caroliniana, Lycopodiella cernua and Pityrogramma sp. (Pteridaceae) (Fig. 3). The presence of these pteridophytes indicates a humid condition in a permanently water-logged environment.

\section{Zone D (4,785-50 cal. yr BP)}

Thelast 4,785years in the studied section experienced the highest pollen concentration (at 2,705 cal. yr BP) (Fig. 5); owever, the curve decreases upwards accompanied by an increase in granulometry, mainly due to sand deposition. The herbaceous flora - e.g. Poaceae (1.8\%) and Cyperaceae (5.5\%) - had its lowest abundance in the studied section accompanied by increasing Gleichenia sp. (6.4\%), which is commonly associated with waterlogged soils or shallow lakes. Other pollen taxa present indicative of humid and woody environments include Pseudobombax sp. (1.2\%), Tabebuia sp. (0.7\%), Vernonia sp. (1.8\%), Senecio sp. (0.5\%), Sena sp. (1.4\%), Mimosa sp. (0.2\%), Protium sp. (0.5\%), Maprounea brasiliensis (3.0\%) and Typha sp. (5.4\%) (Fig. 3) (Colinvaux et al. 1999; Mendonça et al. 2008; Cassino 2010; Lorscheitter et al. 2002; Medeiros 2011). In summary, the herbaceous flora recorded its lowest abundance and was replaced by other vegetation groups (e.g. swamp, cerrado, Atlantic forest). The topmost sample ( $50 \mathrm{yr}$ ) represents the contemporary environment of today - a seasonally water-logged situation - and therefore reflects the colmatation of the lacustrine system. 


\section{Conclusions}

Overall, our results show that the vegetation in the region of PERD has undergone slight continuous historical change from fluvial to lake environments with a subsequent colmatation of this system. The sequence of vegetation change included a progressive increase in diversity. The following conclusions were drawn from the results of the palynomorphs assemblage and ecological indices for the Lc-2-01 section:

The taxa recorded in the studied section contain moderately well preserved palynomorphs dominated by pollen grains of Poaceae and Cyperaceae.

The palynomorphs represent five distinctive vegetation groups: (swamp, cerrado, Atlantic forest, gallery forest and altitudinal forest) plus algae.

The first record of Mauritia flexuosa at 9,350 cal. yrs BP indicates the occurrence of modern-day "veredas" (palm swamps today). This vegetation community supports represents a swampy or water-logged forest, and is corroborated by the co-occurrence of algae, especially Spirogyra.

The main increase in diversity of vegetation in the studied section occurred from 4,785 cal. yr BP to the present.

The pollen grains and spores recorded throughout the studied core are consistent with the riparian forest and savanna vegetation characteristic of the region surrounding PERD. The grains described by the palynological data represent riparian forest, gallery forests, wetlands, trails and humid forest, which suggests that much of the recovered vegetation is local. Another portion of the recovered pollen grains are characteristic of the cerrado, reflecting the predominant vegetation surrounding PERD. The historical transformation of the environment resulted in increased in abundance and diversity.

The recent event of the occurrence of a mesic, denselyforested ecosystem in the mid-basin of the Rio Doce raises concerns about the future of this biota. The region has suffered severe hydrologic deficit in recent years, with less precipitation than evapotranspiration. As a result, the lakes are drying and water has become more distanced from the forests, resulting in eventual changes to the energy flow between these two component ecosystems. Could the forest change back to a savanna type of vegetation? Or is this a temporary event? Whatever the case, after a recent huge mud slide resulting from a mining dam disaster in the upper basin of the river, the interactions between forest and river and forest and lakes may be instrumental to restoration of the entire river basin. Tracing past to future changes in the ecological communities of the region is fundamental for management of its natural resources and for conserving nature that has been so dramatically impacted.

\section{Acknowledgements}

This study was supported by the Conselho Nacional de Desenvolvimento Científico e Tecnológico (CNPq) and Coordenação de Aperfeiçoamento de Pessoal de Nível Superior (CAPES) which provided scholarship to F.M. Fonseca-Silva. We thank the Departamento de Geologia da Universidade Federal de Ouro Preto-MG for facilitating the logistics required to collect the core and perform laboratory tests.

\section{References}

Algaebase. 2012. Identificação de algas. http://www.algaebase.org. 15 Nov. 2012.

Barbosa GV, Kohler HC. 1981. O sistema lagunar do Parque Estadual do Rio Doce (MG). Boletim da SBG-MG 2: 37-46.

Cassino RF. 2010. Reconstituição do Clima e da Vegetação do Chapadão dos Gerais, a partir da análise palinológica da Vereda Laçador. MSc Thesis, Universidade Federal de Minas Gerais, Belo Horizonte.

Cassino RF, Meyer KEB. 2011. Morfologia de grãos de pólen e esporos de níveis holocênicos de uma vereda do Chapadão dos Gerais (Buritizeiro, Minas Gerais), Brasil. Gaea 7: 41-70.

Cassino RF, Meyer KEB. 2013. Reconstituição paleoambiental do Chapadão dos Gerais (Quaternário tardio) a partir da análise palinológica da Vereda Laçador, Minas Gerais, Brasil. Revista Brasileira de Paleontologia 16: 127-146.

Colinvaux PA, Oliveira PE, Moreno JE. 1999. Amazon pollen manual and atlas. New York/ Harwood, Ed. Academic Press.

Fonseca-Silva FM, Carvalho MA, Ribeiro SP. 2015. Caracterização da matéria orgânica particulada dos últimos 10 mil anos a partir de um testemunho do parque estadual do rio Doce, MG, Brasil: Implicações paleoambientais. Revista Brasileira de Paleontologia 18: 161-170.

Freitas AG, Carvalho MA, Mendonça Filho JG. 2007. Description of Bryophyte and fern spores and fresh-water algae of PleistoceneHolocene sediments of Albacora Slope, Campos Basin, RJ, Brazil. In: Carvalho IS, Cassab RT, Schwanke C, et al. (eds.) Paleontologia: cenários de vida. Vol 2. Rio de Janeiro, Interciência. p. 457-470.

Geominas. 2010. Mapa de vegetação do estado de Minas Gerais, Brasil. www.ide.ufv.br/geominas. 8 May 2014.

Gilhuis JP. 1986. Vegetation survey of the Parque Florestal Estadual do Rio Doce, MG, Brazil. MSc Thesis, Universidade Federal de Viçosa, Viçosa.

Gomes MOS. 2008. Caracterização palinológica dos sedimentos do quaternário da bacia do rio Maracujá - MG. Programa de PósGraduação em Evolução Crustal e Recursos Naturais. MSc Thesis, Universidade Federal de Ouro Preto, Ouro Preto.

Grenfell HR. 1995. Probable fossil zygnematacean algal spore genera. Review of Palaeobotany and Palynology 84: 201-220.

Grimm EC. 1987. Coniss: A Fortran 77 progam for stratigrafhically constrained cluster analysis by the method of the incremental sum of squares. Pergamon Journal 13: 13-35.

Hammer C, Mayewski PA, Peel D, Stuiver M. 2008. Greenland summit ice cores GISP2/GRIP. Journal of Geophysical Research 102: 92 [Special issue]

Hill BM. 1975. A simple general approach to inference about the tail of a distribution. The Annals of Statistics 3: 1163-1174.

IEF - Instituto Estadual de Florestas. 2010. Cobertura vegetal de Minas Gerais. http://www.ief.mg.gov.br/florestas. 13 Aug. 2010.

Justo RL. 2003. Caracterização palinológica de depósitos fluviais recentes da Região do Médio Vale do Rio Doce (MG). MSc Thesis, Universidade Federal do Rio de Janeiro, Rio de Janeiro.

Leal M, Lorscheitter ML. 2006. Pólen, esporos e demais palinomorfos de sedimentos holocênicos de uma floresta paludosa, Encosta Inferior do Nordeste, Rio Grande do Sul, Brasil. Iheringia, Série Botânica 63: 69-100. 
Leonhardt A, Lorscheitter ML. 2007. Palinomorfos do perfil sedimentar de uma turfeira em são Francisco de Paula, Planalto Leste do Rio Grande do Sul, sul do Brasil. Revista Brasileira de Botânica 30: 47-59.

Lopes WP, Silva AF, Souza AL, Meira-Neto JAA. 2002. Estrutura fitossociológica de um trecho de vegetação arbórea no Parque Estadual do Rio Doce - Minas Gerais, Brasil. Acta Botanica Brasilica 16: 43-456.

Lorscheitter ML, Ashraf AR, Windisch PG, Mosbrugger V. 2002. Pteridophyte of Rio Grande do Sul flora, Brazil. Part IV. Palaeontographica 263: 1-159.

Lorente FL. 2007. Evolução paleoamebiental da Lagoa do Toquinho, Médio Vale do Rio Doce, MG. Alfenas, Universidade Federal de Alfenas.

Lorente FL, Meyer KEB, Horn AH. 2010. Análise palinológica da vereda da fazenda urbano, município de Buritizeiro, Minas Gerais, Brasil. Revista Geonomos 18: 57 -72.

Marchant R, Behling H, Berrio JC, et al. 2002. Pollen-based biome reconstructions for Colombia at 3000, 6000, 9000, 12 000, 15000 and $1800014 \mathrm{C}$ yr ago: Late Quaternary tropical vegetation dynamics. Journal of Quaternary Science 17: 113-129.

Medeiros JD. 2011. Guia de campo: vegetação do Cerrado 500 espécies. Brasília, MMA/SBF.

Meis MRM. 1977. As unidades morfo-estratigráficas neo-quaternárias do Médio Vale do Rio Doce. Anais da Academia Brasileira de Ciências 493: 443-459.

Meis MRM, Monteiro ANF. 1978. Upper Quaternary “Rampas”: Doce River Valley, Southeastern Brazilian Plateau. Zeitschrift für Geomorphologie, Sttutgart 23: 131-151.

Mello CL. 1997. Sedimentação e tectônica Cenozóicas no Médio Vale do Rio Doce (MG, Sudeste do Brasil) e suas implicações na evolução de um sistema de lagos. PhD Thesis, Universidade de São Paulo, São Paulo.

Mello CL, Metelo CMS, Suguio K, Kohler HC. 1999. Quaternary sedimentation, neotectonics and the evolution of the Doce River Middle Valley lake system (Southeastern Brazil). Revista do Instituto Geológico 20: 29-36.

Mendonça RC, Felfili JM, Walter BMT, et al. 2008. Flora vascular do bioma Cerrado: um "checklist" com 11.430 espécies. In: Sano SM, Almeida SP, Ribeiro JF. (eds.) Cerrado: ecologia e flora. Brasília, Embrapa Informação Tecnológica. p. 423-1279.

Nimer E.1989. Climatologia do Brasil. Rio de Janeiro, IBGE.

Oliveira C, Araújo P, Mazu N. 2002. Fundamentos da ciência do solo. 2nd. edn. Seropédica, Universidade Federal Rural do Rio de Janeiro.

Overloop E. 1981. Post-glacial to holocene transition in a peatlayer of Lake Jacaré (Rio Doce basin, Brazil). Bulletin de la Société Belge de Géologie 90: 107-119.
Perônico C. 2008. Estudo do preenchimento sedimentar de lagoas em fase de assoreamento na região do médio Rio Doce - Minas Gerais. PhD Thesis, Universidade Federal de Ouro Preto, Ouro Preto.

Pflug R. 1969. Quaternary lakes of Eastern Brazil. Photogrammetria 24: 29-35.

Punt W, Hoen PP, Blackmore S, Nilsson S, Thomas A. 2007. Glossary of pollen and spore terminology. Review of Palaeobotany and Palynology 143: 1-81.

Ratter JA, Bridgewater S, Ribeiro JF. 2003. Analysis of floristic composition of the Brazilian cerrado vegetation III: comparison of the woody vegetation of 376 areas. Journal of Botany 60: 57-109.

Ribeiro RF. 2002. O Eldorado do Brasil Central: história ambiental e convivência sus-tentável com o Cerrado. In: Alimonda H. (ed.) Ecología política, naturaleza, sociedad y utopia. Buenos Aires, CLACSO. p. 249-275.

Rodrigues Filho S, Behling H, Irion G, Müller G. 2002. Evidence for lake formation as a response to an inferred Holocene climatic transition in Brazil. Quaternary Research 57: 131-137.

Sano SM, Almeida SP, Ribeiro JF. 2008. Cerrado: ecologia e flora. Vol. 1. Viçosa/MG, Embrapa Informação Tecnológica.

SOCT - Sistema Operacional de Ciência e Tecnologia. 1981. Programa de pesquisas ecológicas no Parque Florestal Estadual do Rio Doce. Vol. 2. Belo Horizonte, CETEC.

Toledo MB, Bush MB. 2008. Vegetation and hydrology changes in Eastern Amazonia inferred from a pollen record. Anais da Academia Brasileira de Ciências 80: 191-203.

Vasconcelos SG, Saadi A. 2003. O Quaternário do médio rio Doce: aporte da morfodinâmica e do aluvionamento na confluência dos rios Piracicaba e Doce. In: IX Congresso da Associação Brasileira de Estudos do Quaternário. Recife, ABEQUA.

Veloso HP, Rangel Filho ALR Lima JCA. 1991. Classificação da vegetação brasileira, adaptada a um sistema universal. Rio de Janeiro, IBGE.

Walter BMT. 2006. Fitofisionomias do bioma Cerrado: síntese terminológica e relação florística. PhD Thesis, Universidade de Brasília, Brasília.

Ybert JP, Labouriau S, Barth ML. 1992. Sugestões para padronização da metodologia empregada em estudos palinológicos do Quaternário. Revista do Instituto Geológico 13: 47-49.

Ybert J-P, Albuquerque ALS, Turcq B. 1997. Evolução paleoclimática e paleoambiental na Região do Vale Médio do Rio Doce (Minas Gerais, Brasil). In: Anais do VI Congresso da Associação Brasileira de Estudos do Quaternário. Curitiba. p. 511-514.

Ybert J-P, Carvalho MA, Scheel-Yber TR. 2012. Dicionário temático de morfologia esporopolínica. Vol. 1. 1st. edn. Rio de Janeiro, Livros Museu Nacional. 